\title{
A Study on the Relations Between Chinese Government and Private Enterprises on the Course of Internationalization -A Case of Huajian Group ${ }^{1}$
}

\author{
Chen Siying \\ School of English for International Business, \\ Guangdong University of Foreign Studies, Guangzhou, China, 510420 \\ Wu Yiming \\ School of English for International Business, \\ Guangdong University of Foreign Studies, Guangzhou, China, 510420
}

\begin{abstract}
The study illustrates the results of a research aimed at exploring the relations between government and private enterprises in the process of Internationalization. Taking Huajian Group as the case study object, the study centers on two issues. The primary issue is to identify how the government-enterprise relations during the case analysis have changed over time; on the other hand, the study focuses on goal orientation of the relations between government and private enterprises on a firm basis. In order to diagnose these problems, qualitative and quantitative methods are used through the whole study. Besides the literature study, a questionnaire and a semi-structure interview are conducted to acquire data and information. In particular, SERVQUAL model is applied for the design and orientation of the government-enterprise relations in support of Internationalization. The results demonstrate that the relations characterized by cooperation and mutual assistance may play a crucial role in the process of Internationalization for Chinese private enterprises. It is suggested that legal aids and guidance from Chinese government are essential for Chinese private enterprises, for it could provide reference for the establishment of an effective relations and clearer positioning of government in a global market.
\end{abstract}

Key words: Chinese private enterprise; Internationalization; Government-enterprise relations; Huajian Group

\section{INTRODUCTION}

The relations between enterprise and government have always been a heated topic in studies on public management and business management, and it is also a topic that shall not be ignored by governments at all levels and enterprises in actual operation. While various definitions are given to describe the relations between government and enterprise, more consensus are found in the basic characteristics: it involves the interaction and mutual influence between Governments and enterprises. Over the past decades, political scientists and economists have been working to deconstruct the types and connotations of the governmententerprise relations. Masahiko (1998) divided the government-enterprise relations into three basic categories: authoritative governance, power-dependency and rules-based management. Fu and Fang (2004) classified the relations into three distinctive types, that is, direct control,

\footnotetext{
1 This research was supported by the Research Foundation for Talented Scholars in Guangdong University of Foreign Studies-a study on the relations between Chinese government and private enterprises on the curse of Internationalization: a case of Huajian Group.
} 
indirect guidance, and coordination \& cooperation. Nevertheless, the relation is not static; instead, it proceeds from the general to the specific and complex due to the consistency of government functions and duality (Pan and Mo, 2005).

It is not uncommon for government to adjust and strive for excellence in relations to business (or corporations take initiatives), but what are the causes of the attempts? Some scholars have studied the economic benefits that corporations gain from the government-enterprise relations. The implication is that well-established political ties facilitate companies' access to tax credit, bank loans and other forms of government supports (Claessens et al, 2008; Bunkanwanicha et al, 2008; Faccio, 2006; Fisman, 2001). Under the background of China's allround transformation as a relations-oriented society, the relations between Enterprise and enterprise are of paramount significance for private enterprises. As pointed out in previous reviews (Luo et Tang, 2009; Chou and Tao, 2009; li, 2008; li, 2006),some private enterprises have managed to establish close relationship with governments at certain levels, which serve a useful communication function related to political interests and economic benefits.

A new approach to examining how government-enterprise relations affect enterprises-from the perspective of internationalization-have been interesting some scholars in recent years. Based on the interactive effects between public sectors and private sectors in the United States and some European countries, it is observed that private individuals or groups are not simply putting pressure, but trying to building up relationships with governments on the basis of information sharing and mutual learning. The transformation of the government-enterprise relations exerts a significant impact on both private interests and international negotiations (Cornelia et al, 2010). Brian et al (2012) delve into how the intervention of government and financial institutions affects the degree of internationalization in Japan and Taiwan, and argue that when government departments attempt to establish a close bond, as a way to promote international market expansion, what were expected to be desirable actually have brought counterproductive effects to the internationalization-it will inevitably discourage board of directors and restrain their abilities in corporate supervision. Song et al (2018) found that since politics, economics, laws and cultures, etc., vary in the countries along the Belt and Road, enterprise-government cooperation suggested by the initiative is more dependent on government policy and behavior than under other circumstances.

Additionally, differences in civilizations indicate that no government-enterprise relations can be applicable to all countries. Even for a single country, as national conditions and requirements change, the relations between government and enterprise, which was originally compatible with its own development, may not be suited to the needs of social development for the time being. According to the dynamic force model, society is a network of various factors affecting each other, where governments and enterprises are subject to multiple pressures. Environmental forces, including economic and non-economic forces, can trigger a significant impact on business through policy, while businesses can also influence other social factors, government included. Therefore, the relation between government and enterprise is expected to undergo various modifications in response to changes in social value, participants and social structure.

As China reinforces its reform of opening up, more and more enterprises gain new opportunities for development through the "going out" strategy. Especially after the Third Plenary Session of the 18th Central Committee of the CPC, the Government is transforming its functions to be more service-oriented and create a fair business environment where the government-enterprise relations will change further. However, emphasis has merely been laid on the relations between governments and state-owned enterprises. 
With the advancement of market economy, private enterprises have become a new engine of China's economic development and opening-up policy to the globe. But what are the relations between the government and private enterprises when the country enters a new stage of comprehensively deepening reform and further opening-up? What are the impacts of the relations? How may it better be promoted? Thus, this paper studies the relations between private enterprises and the government under the background of internationalization.

Nowadays, with the proposal of the B\&R (Belt and Road) Initiative, many African countries have attracted a large amount of investment from Chinese private enterprises, e.g. Huajian Group. It should be noticed that future changes in international and domestic environment will not only affect Chinese government's policy concerning African countries and enterprises' investment, but also affect the government-enterprise relations.

Taking Huajian Group as an example, this study aims at exploring how the target enterprise interacts with government on the course of Internationalization. Combining qualitative and quantitative methods, a literature study, a questionnaire and a semi-structure interview are conducted to acquire data and information. SERVQUAL model is applied for the design and orientation of the government-enterprise relations in support of "going out" strategy. This, in essence, intends to discover how to facilitate government's support and services for enterprises.

The study is to cover the following issues:

1. What are the changes regarding the relations between Chinese government and Huajian Group since the enterprise began its foreign direct investment in Africa? More specifically, how the relations have been changing in recent years?

2. What are the evaluation and demand of the Huajian Group toward Chinese government in the service for Internationalization?

\section{Company Profile}

\section{RESEARCH DESIGN AND PROCESS}

Huajian Group, founded in 1996, is a Chinese women's leather shoemaker, headquartered in Dongguan, Guangdong province, China. The company specializes in the production of highquality leather shoes. As of 2018, the firm employs approximately 28,000 people and owns 40 shoemaking lines. Its footwear business encompasses facilities across China in Dongguan, Ganzhou and Yunnan as well as Ethiopia, Africa. It covers a wide range of sectors from leather making, materials, shoemaking, equipment assembling and logistics. Since 2011, Huajian has begun investing on Huajian International Shoe City, shoemaking facilities at the Oriental Industrial Zone in the Oromia region of Ethiopia. By 2017, its branch in Ethiopia employs 3200 people, and produces 2,400,000 pairs of shoes in Ethiopi every year, whose output accounts for about 50 percent of the gross domestic product of Ethiopia shoemaking industry.

\section{Research Design}

In this study, we first conduct a semi-structural interview with the managers of various levels of the Huajian Group, in order to summarize the main points of the survey subjects on the evolution of the relations between Huajian Group and the government before and after its internationalization. The study aims at providing a reference for the design of the questionnaire and the future research model. It may provide some hints for the internationalization construction and innovative practice of some enterprises under similar circumstances. 
This interview targets at top management ( 3 people), management ( 1 person), and low management (1 person), each controlled in 30-60 minutes.

After analyzing the results of interview, this study applies a questionnaire to the a further understanding of staff's evaluation and expectation for Huajian Group, in terms of the current government-supported services and future services. The questionnaire was designed and distributed at the end of April 2018. The survey was mainly conducted among the Huajian Group's management personnel at various levels and was recovered on May 5, 2018 ${ }^{[10] .}$

The questionnaire has 28 questions in total, which mainly includes two parts: the basic information of respondents and the quality of government services. The demographic variables consist of gender, age, job title, job role, and amount of time to work abroad [11]. The table that outlines government service quality is based on the SERVQUAL model, which combines the interview analysis of the HuaJian Group's personnel and the actual situation of HuaJian. This questionnaire selects 23 rating indicators, and thus comprises 46 questions, including 23 questions of government service expectations and 23 questions about the actual experience of the service.

Expected value is a measurement of respondents' expectation for the government service during the internationalization of Huajian. The perceived value is used to examine respondents' perception of the quality of government-provided services.

Questionnaires for this survey were distributed and recovered through the Internet. The survey distributed 50 questionnaires totally, in which 48 were recovered, of which 45 were valid and the effective rate was $93.75 \%$.

\section{Research Model}

The service evaluation SERVQUAL model[9] was proposed in 1985 by scholars Parasuraman, Zeithaml and Berry. This model is originally used as an instrument to measure service quality and customer satisfaction as well as suggest possible causes of customer service problems.

The evaluation of government service quality is similar to the evaluation of consumer service quality, which proposes a scale for expectations and actual perception of government service recipients (enterprises, citizens, etc.) on government service. The expectations and actual perception can serve as a benchmark for the improvement of government service.

Therefore, this paper applies the SERVQUAL model to evaluate the current service of government's support for internationalized companies as a basis for judging the role of government and the government-enterprise relationship.

The model includes four dimensions: economic support, information exchange, market development support, and equity maintenance. Measurement items are designed under four dimensions involving the economy, information, and legal support.

\section{Research Process \\ Interview}

With regard to the relationship before Huajian Group went international in 2011, most interviewees subscribe to the belief that government's decisive role in politics, economy, and society had made itself the most important stakeholder of the company. Consequently, how to deal with the relations with government (especially the local government) inevitably became a significant and challenging task for company. Moreover, the "GDP championship" had 
strengthened the government's willingness to control and intervene in enterprises, coupled with Chinese culture's emphasis on "Guanxi" and rent-seeking activities by means of power regulation. Overall, the government was more of a controller and stakeholder to Huajian Group before 2011. It represents a government-enterprise relation centered on government direct management.

However, the year 2012 witnessed an enormous change. On the one hand, financial crisis led to the decline in asset prices among many countries and regions, which instead, prompted Chinese companies to undertake overseas investment. Many western countries' demand for consumption and OEM were also severely affected. On the other hand, the rapid rise in domestic price and production cost, partly attributed to the decline of demographic dividends, has undermined the competitive edge of Chinese export-oriented enterprises and laborintensive enterprises in the global market. The fast-changing world has therefore, not only resulted in the political and public awareness in the importance and necessity of internationalization strategy, but also stimulated Huajian Group to proritize "going international", transfer and optimize its manufacturing processes, as well as extend its industrial distribution nework to a global scale, according to semi-structual interview.In other words, both the government and company have been actively participating in the efforts of "going international", resulting in a change of mutual relationship. The government has gradually evolved from direct controllers and stakeholders to indirect guides, supporters, and service providers.

At present, governments at all levels have announced that efforts would be made to speed up the development of the overseas economic and trade cooperation zone of Huajian International Light Industry City, in the hope of attracting more investment and talents. As mentioned by a senior executive, Huajian Group's active play in "going international" and the positive results achieved have further strengthened governments'support.

For example, during the construction of the Ethiopian industrial park, Chinese central government, provincial and municipal governments signed up for friendship alliances with the corresponding Ethiopian government at various levels.They established a communication platform for policy and legal issues. More policies have been promulgated in customs, taxation, finance, law, and social intelligence services to provide comprehensive support for Huajian Group and other Chinese companies in Ethiopia.

In summary, since Huajian's went international in 2011, Huajian's relations with government have evolved due to changes in the external environment, as well as its needs and government's role, which progess from the initial direct control, indirect guidance to coordination \& cooperation. The government and the enterprises have relegated their positions to become equal entities of autonomy. Thus, the way of gambling is shifted from a guanxi game to a rule-based game. In the future, the government is expected to play a fundamental role more of a supporter and service provider for Huajian Group to progress in the foreign markets.

\section{Questionnaire}

\section{a) KMO Test and Bartlett Test}

This study uses factor analysis to identify the dimensions of the quality assessment model of the government support for going international. Through factor analysis, of 23 evaluation indicators, the ones with relatively high correlation are grouped into one category to become a "public factor", that is, the dimension for measuring the government service quality concerning 
Huajian Group's "going international”. According to the KMO test standard, from Table 2-1, the KMO of this study is 0.729 , which makes it suitable for factor analysis. The Bartlett sphere test statistic is 701.195, and the corresponding significance level is 0.000 , both consistent with the standard of significant difference between the correlation coefficient matrix and the unit array. Thus, the questionnaire is considered to be suited to factor analysis.

Table 2-1 KMO Test and Bartlett Test

\begin{tabular}{c|c|c}
\hline \multicolumn{3}{c}{ Testing by KMO and Bartlett } \\
\hline \multicolumn{2}{c}{ Kaiser-Mever-Olkin statistics } & 0.729 \\
\hline \multirow{3}{*}{ Bartlett's sphericity test } & Approximate Chi-square & 701.195 \\
\cline { 2 - 3 } & Degree of freedom & 253 \\
\cline { 2 - 3 } & Significant level & 0.000 \\
\hline
\end{tabular}

\section{b) Exploratory Factor Analysis}

After factor analysis, this study applies principal component analysis to determine the number of public factors of the researched model of the government service. The results show that four major factors account for the most of the variance of variables, whose cumulative contribution to the variance amounts to $75.760 \%$ (Table $2-2$ ).

Table 2-2 Overall Variance Interpretation of Factor Analysis

\begin{tabular}{|c|c|c|c|c|c|c|}
\hline \multirow[b]{2}{*}{ Ingredients } & \multicolumn{3}{|c|}{ Initial feature value } & \multicolumn{3}{|c|}{ Rotation squared and loaded } \\
\hline & total & Variance \% & Accumulation \% & total & Variance \% & Accumulation \% \\
\hline 1 & 11.540 & 51.477 & 51.477 & 11.540 & 51.477 & 51.477 \\
\hline 2 & 2.399 & 10.431 & 61.908 & 2.399 & 10.431 & 61.908 \\
\hline 3 & 1.671 & 7.265 & 69.173 & 1.671 & 7.265 & 69.173 \\
\hline 4 & 1.285 & 6.587 & 75.760 & 1.285 & 6.587 & 75.760 \\
\hline 5 & 0.982 & 4.521 & 76.281 & & & \\
\hline 6 & 0.978 & 4.251 & 77.032 & & & \\
\hline 7 & 0.909 & 2.849 & 79.281 & & & \\
\hline 8 & 0.654 & 2.614 & 81.130 & & & \\
\hline 9 & 0.494 & 1.976 & 83.474 & & & \\
\hline 10 & 0.438 & 1.754 & 84.792 & & & \\
\hline 11 & 0.330 & 1.319 & 86.851 & & & \\
\hline 12 & 0.265 & 1.058 & 88.803 & & & \\
\hline 13 & 0.238 & 0.952 & 90.699 & & & \\
\hline 14 & 0.224 & 0.895 & 91.766 & & & \\
\hline 15 & 0.146 & 0.584 & 92.214 & & & \\
\hline 16 & 0.121 & 0.484 & 93.604 & & & \\
\hline 17 & 0.112 & 0.448 & 95.963 & & & \\
\hline 18 & 0.097 & 0.390 & 96.242 & & & \\
\hline 19 & 0.090 & 0.360 & 97.447 & & & \\
\hline 20 & 0.070 & 0.279 & 98.753 & & & \\
\hline 21 & 0.051 & 0.204 & 99.938 & & & \\
\hline 22 & 0.041 & 0.141 & 99.988 & & & \\
\hline 23 & 0.026 & 0.051 & 100.000 & & & \\
\hline
\end{tabular}




\section{c) Rotation of Orthogonal Factors}

In case that the information corresponding to each factor is intuitively interpreted, which results in ambiguity to the meaning of the factor and overlap of factor information, the initial factor is rotated with the maximum variance method in orthogonal rotation. In the postrotation questionnaire, items with load values greater than 0.4 in more than two factors will be deleted to maximize the interpretation of the variance of the original data whereby the public factor can be more clearly identified and interpreted. It was found that the factor "commercial bank's preferential loans for enterprises to invest abroad" and "the number of financial institutions aimed at supporting enterprises to go abroad" had a load value of more than 0.4 on two factors, so they were deleted. Thus, the final load matrix is shown in Table 2-3 above.

Table 2-3 Final load matrix

\begin{tabular}{|c|c|c|c|c|}
\hline & 1 & 2 & 3 & 4 \\
\hline $\begin{array}{l}\text { 6、Amount of special funds } \\
\text { 7、Special funds in place } \\
\text { 8、Credit guarantees } \\
\text { 9、 Foreign exchange loan support } \\
\text { 12、 Supportive tax subsidies } \\
\text { 13、 Corporate tax benefits } \\
\text { 14、 Overseas park construction support } \\
\text { 15、 Communication and cooperation with } \\
\text { foreign government in park construction } \\
\text { 16、 Support for overseas industrial clusters } \\
\text { 17、 Number of seminars or meetings organized } \\
\text { by the government } \\
\text { 18、 Government guidance at chambers of } \\
\text { commerce and associations } \\
\text { 19、Government-supported database } \\
\text { 20、 E-commerce platform construction \& } \\
\text { maintenance } \\
\text { 21、 Government's collection of industry } \\
\text { information } \\
\text { 22、 Efficiency of approval process } \\
\text { 23、Effectiveness of management training } \\
\text { 24、Policy of talents' "going international" } \\
\text { 25、Overseas security warning mechanism } \\
\text { 26、Offshore safety rehabilitation mechanism } \\
\text { 27、Overseas legal guidance } \\
\text { 28、 Follow-up feedback on legal rights }\end{array}$ & $\begin{array}{l}0.730 \\
0.789 \\
0.745 \\
0.555 \\
0.529 \\
0.512\end{array}$ & $\begin{array}{c}.827 \\
.759 \\
\\
.699 \\
.643 \\
. \\
632 \\
. \\
753 \\
.770 \\
.841\end{array}$ & $\begin{array}{l}.603 \\
.623 \\
.576\end{array}$ & $\begin{array}{l}.736 \\
.529 \\
.794 \\
.591\end{array}$ \\
\hline
\end{tabular}

\section{d) Naming of Dimensions}

Based on the above analysis, this article has screened and selected 21 evaluation items of the SERVQUAL assessment model for government service quality in support of Huajian Group to "go international". As can be seen from Table 2-4, all 21 items are subcategorized to 4 common factors-four dimensions within SERVQUAL model.

Dimension 1 contains 6 items. These items are related to the government's economic support, such as special funds, levy, and financing services. Therefore, this factor is named "Economic Support"; Dimension 2 contains 8 items which are related to government support for the construction of overseas parks, integration into local industrial clusters, information sharing, and e-commerce platforms, and hence the factor was titled "Information Sharing Support"; 
Dimension 3 consists of three items regarding government's support towards overseas business development, including approval process, management training, and talents cultivation, all named after "Market Development Support"; Dimension 4 contains 4 items, which covers security, law, and other aspects related to the government's service in the process of "going international", namely, "Rights and Interests Protection".

Table 2-4 Naming and Summary of Dimensions

\begin{tabular}{|c|c|c|c|c|}
\hline \multirow[b]{2}{*}{ Items } & \multicolumn{4}{|c|}{ Dimension } \\
\hline & $\begin{array}{c}\text { Economic } \\
\text { Support }\end{array}$ & \begin{tabular}{|c|} 
Information \\
Sharing \\
Platform \\
\end{tabular} & \begin{tabular}{|c|} 
Market \\
$\begin{array}{c}\text { Development } \\
\text { Support }\end{array}$ \\
\end{tabular} & $\begin{array}{c}\text { Rights\& } \\
\text { Interests } \\
\text { Protection } \\
\end{array}$ \\
\hline 6、The amount of special funds & .730 & & & \\
\hline 7、 Special funds in place & .789 & & & \\
\hline 8、 Credit guarantees & .745 & & & \\
\hline 9、Foreign exchange loan support & .555 & & & \\
\hline 12、Supportive tax subsidies & .529 & & & \\
\hline 13、 Corporate tax benefits & .512 & & & \\
\hline 14、 Overseas park construction support & & .827 & & \\
\hline $\begin{array}{l}\text { 15. Communication and cooperation with } \\
\text { foreign government in park construction }\end{array}$ & & .759 & & \\
\hline $\begin{array}{l}\text { 16. Support for integration into overseas } \\
\text { industrial clusters }\end{array}$ & & .699 & & \\
\hline $\begin{array}{l}\text { 17、 Number of seminars and meetings } \\
\text { organized by the government }\end{array}$ & & .643 & & \\
\hline $\begin{array}{l}\text { 18、 Government guidance at chambers of } \\
\text { commerce and associations }\end{array}$ & & .632 & & \\
\hline 19、Government-supported database & & .753 & & \\
\hline $\begin{array}{l}\text { 20、E-commerce platform website } \\
\text { construction and maintenance }\end{array}$ & & .770 & & \\
\hline $\begin{array}{l}\text { 21、 Government's collection of industry } \\
\text { information }\end{array}$ & & .841 & & \\
\hline 22、 Efficiency of approval process & & & .603 & \\
\hline $\begin{array}{l}\text { 23、 Effectiveness of management training } \\
\text { organized by the government }\end{array}$ & & & .623 & \\
\hline 24、Policy of talents' "going international" & & & .576 & \\
\hline 25、Overseas security warning mechanism & & & & .736 \\
\hline 26、 Offshore safety rehabilitation mechanism & & & & .529 \\
\hline 27、Overseas legal guidance & & & & .794 \\
\hline 28. Follow-up feedback on legal rights & & & & .591 \\
\hline
\end{tabular}




\section{e) Reliability Analysis}

With SPSS 18.0 software package, the study conducts a Cronbach's alpha test to determine the reliability of the SERVQUAL model of government "going international" support for Huajian Group.

The results are shown in Table 2-5 as below.

Table 5 Cronbach's $\alpha$ Test

\begin{tabular}{c|c|c}
\hline & Dimension & Cronbach's $\alpha$ \\
\hline 1 & Economic support & 0.89 \\
\hline 2 & $\begin{array}{c}\text { Information sharing } \\
\text { support }\end{array}$ & 0.83 \\
\hline 3 & $\begin{array}{c}\text { Market development } \\
\text { support }\end{array}$ & 0.85 \\
\hline 4 & Interest \& rights protection & 0.82 \\
\hline
\end{tabular}

As the above table shows, Cronbach's $\alpha$ of government's support in economics, information sharing, market development, and rights \& interests protection are higher than 0.8 , indicating that the overall items and dimensions are relatively reliabile, and thus verified the application of SERVQUAL model for examining government supporting services designed and researched in this study.

\section{An Overview of Recent Changes}

\section{RESEARCH RESULTS}

During the interview, interviewees are asked to discuss 1) the reasons for the implementation of the "going international" strategy, 2) the type of relations between the Government and the enterprise before and after international strategy, 3) and how the interactive governmententerprise relations influence the implementation of the strategy. This interview mainly focuses on top management, considering the possibility that top managers may have a better understanding of the overall situation of the enterprise and a comprehensive perspective. The results are summarized in order to provide some guiding significance for other enterprises in team building and innovation practice.

Through the literature review and semi-structural interview, as a combination of dynamic power model, three conclusions are drawn as follows:

1. External environment is one of the most important factors for change in the relations between government and Huajian Group. Meanwhile, Huajian's positive attitude for change and timely role shift of the government exert an enormous effect on the relations.

2. Huajian's success benefits not only from its harmonious and effective relation with Chinese government, but also from its timely and comprehensive response to the external environment.

3. In the future, it is believed that Huajian Group is to persist in international strategy. Facing more complicated environment, the relation is expected to bear on the characteristics of indirect guidance and mutual assistance. The government will serve more function in its support and services. 


\section{Thematic Analysis}

According to the evaluation methods of SERVQUAL model ${ }^{2}$, the staff of Huajian Group filled out the questionnaire, including the individual's perceptions and expectations of given government service. Considering the differences in respondents and experts who hold different views of the weight of services provided by the government, the determination of the weight of each dimension is of great necessity.

Determined by the researched expectations, the weight is the ratio of the average expected value of each dimension to the sum of average expectations.

The weight of each dimension is shown in Table 3-1 as below.

Table 3-1 The Weight of Each Dimension

\begin{tabular}{c|c|c}
\hline Dimension(1) & $\begin{array}{c}\text { Average } \\
\text { Expectation(2) }\end{array}$ & $\begin{array}{c}\text { Weight of Dimension } \\
(2) /(3)\end{array}$ \\
\hline Economic support & 4.27 & 0.246 \\
\hline $\begin{array}{c}\text { Information Sharing } \\
\text { Platform }\end{array}$ & 4.26 & 0.245 \\
\hline $\begin{array}{c}\text { Market Development } \\
\text { Support }\end{array}$ & 4.46 & 0.257 \\
\hline $\begin{array}{c}\text { Rights \& interests } \\
\text { Protection }\end{array}$ & 4.33 & 0.25 \\
\hline Total(3) & 17.32 & 1.00 \\
\hline
\end{tabular}

According to the formulas (1), (2) and (3), combined with the scores of each item in the questionnaire, expected value, perceived value and difference value of the government service quality are calculated respectively. The dimension-specific and overall results are shown in Table 3-2.

2 The basic method of SERVQUAL model is gap assessment, ie:

IQ i = IP i - IE i

IQ $\mathrm{j}=\operatorname{IP} \mathrm{j}-\mathrm{IE} \mathrm{j}=\sum \mathrm{i}=1 \mathrm{n}(\mathrm{IP} \mathrm{i}-\mathrm{IE} \mathrm{i})$

$\mathrm{IQ}=\sum \mathrm{j}=14 \mathrm{WJ}(\mathrm{IP} \mathrm{j}-\mathrm{IE} \mathrm{j})=\sum \mathrm{j}=14 \mathrm{WJ} \sum \mathrm{i}-1 \mathrm{n}(\mathrm{IP} \mathrm{i}-\mathrm{IE} \mathrm{i})$

Upon that, i represents the level of item ; $j$ is the level of dimension and $j=1,2,3,4$.

$\mathrm{P}$ represents the expectation of given service quality; $\mathrm{Q}$ represents the perception of perception of given service quality; IP $\mathrm{i}$ is the individual's expected value of each item-— the specific service, and IE i the individual's perceived value of each item; IP j represents the individual's expected value of each dimension-- the general service, IE $\mathrm{j}$ is the individual's perceived value of each dimension; WJ is the weight of each evaluation dimension; Based on the gap in weight ,IQ is regarded as the overall evaluation value, that is the average service quality. Calculate the average service quality via the following formula:

$\mathrm{AVIQ}=\left(\sum \mathrm{i}=1 \mathrm{NIQ}\right) / \mathrm{N}$

Of the formula, AVIQ represents the average perceived quality of the government support for Huajian Group to "go international"; N refers to sample size. 
Table 3-2 Evaluation Results

\begin{tabular}{|c|c|c|c|c|}
\hline Dimension & Item & Expectation (E & Perception (P) & Difference (P-E) \\
\hline \multirow{7}{*}{ Economic support } & 6 & 4.24 & 3.29 & 0.95 \\
\hline & 7 & 4.22 & 3.24 & 0.98 \\
\hline & 8 & 4.27 & 3.29 & 0.98 \\
\hline & 9 & 4.24 & 3.66 & 0.58 \\
\hline & 12 & 4.40 & 3.51 & 0.89 \\
\hline & 13 & 4.27 & 3.47 & 0.80 \\
\hline & Average & 4.27 & 3.41 & 0.86 \\
\hline \multirow{9}{*}{$\begin{array}{c}\text { Information } \\
\text { Sharing Platform }\end{array}$} & 14 & 4.38 & 3.22 & 1.16 \\
\hline & 15 & 4.40 & 3.27 & 1.13 \\
\hline & 16 & 4.16 & 3.29 & 0.87 \\
\hline & 17 & 4.20 & 3.29 & 0.91 \\
\hline & 18 & 4.29 & 3.20 & 1.09 \\
\hline & 19 & 4.24 & 3.49 & 0.75 \\
\hline & 20 & 4.13 & 3.42 & 0.71 \\
\hline & 21 & 4.24 & 3.33 & 0.91 \\
\hline & Average & 4.26 & 3.31 & 0.94 \\
\hline \multirow{4}{*}{$\begin{array}{c}\text { Market } \\
\text { Development } \\
\text { Support }\end{array}$} & 22 & 4.38 & 2.91 & 1.47 \\
\hline & 23 & 4.40 & 3.09 & 1.31 \\
\hline & 24 & 4.60 & 2.89 & 1.71 \\
\hline & Average & 4.46 & 2.96 & 1.50 \\
\hline \multirow{5}{*}{$\begin{array}{l}\text { Rights\&Interests } \\
\text { Protection }\end{array}$} & 25 & 4.29 & 3.40 & 0.89 \\
\hline & 26 & 4.29 & 3.33 & 0.96 \\
\hline & 27 & 4.44 & 3.07 & 1.37 \\
\hline & 28 & 4.29 & 3.16 & 1.13 \\
\hline & Average & 4.33 & 3.24 & 1.09 \\
\hline
\end{tabular}

For a better presentation of the data, the difference between the expected value and the perceived value of each dimension is shown in Figure 3-1.

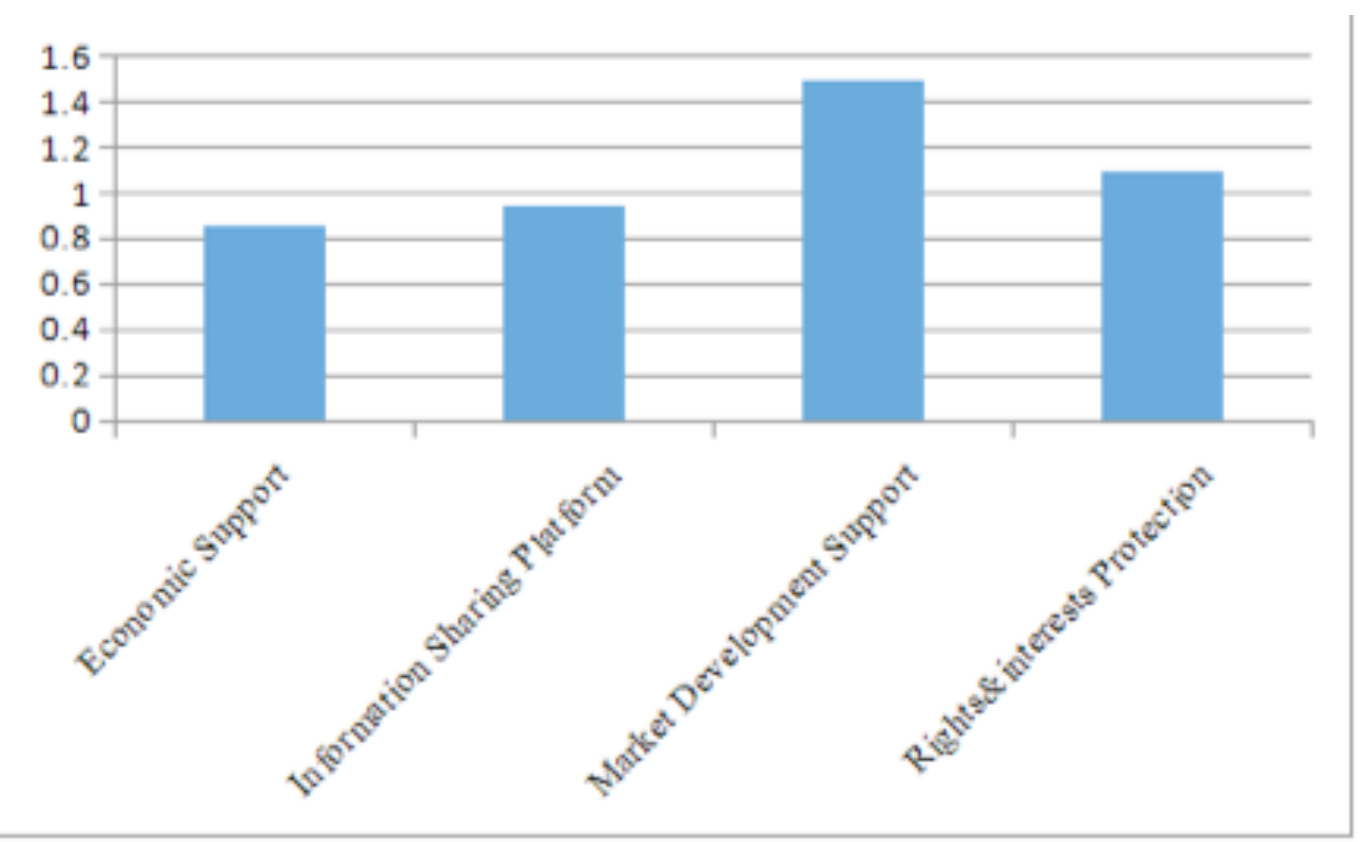

Figure 3-1 Histogram of absolute D-Value of four dimensions 
In general, Huajian Group's expectation for the government's support is higher than the perceived value. More specifically, the company considers that there exists the biggest gap in the market development support, followed by the protection of rights and interests, information sharing platform and economic support.

It suggests that more efforts by the government should be made to meet the needs for market development support and protection for rights and interests during the process of "going international"

\section{CONCLUSIONS AND ECOMMENDATIONS}

This chapter summarizes conclusions and recommendations emerging from the preceding analysis of changes in relations between Chinese government and Huajian Group.

\section{Tailor the Relation to Specific Needs at Various Stages}

From the case of Huajian Group, it is noticeable that during different stages of internationalization, external environment facing the company does not remain to be unchanged. Therefore, the government is in position to play different roles and establish a suitable relation with enterprises. If they suffer from poor management, especially in key areas related to state secrets or national security, the government might directly control as major stakeholders. Otherwise, companies should be entitled to more autonomy and flexibility. At the beginning of overseas market expansion, government had better serve as indirect guider. For example, the government should establish a more complete information database to assist the company's market investigation and development.

When it comes to the initial period of internationalization, the government is advised to provide support and assistance to companies in all aspects, including politics, finance, law, human resources, humanities, etc., thus giving full play to its support and guidance functions. When they enter into the local society, the government should reduce the supervision and control, shifting its role as an escort of collaboration, in order to realize the leading role of market and enterprises.

\section{Establish Future Cooperation and Mutual Assistance}

With regard to the future direction of government-enterprise relations, government should be a supporter and service provider for companies like Huajian Group during internationalization. More specifically, the government and company are expected to work together to achieve cooperation and mutual assistance. This is not only due to the impacts of future external environment, but also to requirements for government in transformation and upgrading as well as the demand for company's development.

Compared with indirect guidance, coordination and cooperation are more suited to the competition of globalization, which reflects joints efforts made by both the government and enterprises to meet the challenges in a broad context. However, this type of relation posts a bigger challenge to both parties. For one hand, government needs not only to strengthen macro-economic control, but also to establish cooperative relations with enterprises, so as to improve their competitiveness without dampening the enthusiasm and innovation. For another, enterprises are required to actively cooperate with the government in all aspects of support for their own developments. Meanwhile, they should provide the government with advanced management ideas and skills, in the hope of further enhancing the government's ability to control the economy. 


\section{Offer Specific Support and Guidance for Internationalization}

Apart from information and economic support, in terms of companies as Huajian Group, the future government service needs to be ameliorated in the aspects of market development and equity protection. The specific measures are manifested as follows.

First of all, the government should work to introduce more policies to encourage college students to work in Africa, by means of preferential policies, such as improving living standard of expatriate staff and solving the education problems of their children. Government is also held accountable for talents cultivation and support.

Additionally, efforts should be made to push reforms that aim to streamline the approval process for companies. Since complicated examination and unnecessary documents turn out to be a hurdle to the internationalization, government should increase simplify the approval process. Besides government's administrative reforms, support from financial institutions such as China Credit Insurance and State Development Bank are indispensable.

Moreover, it is necessary to provide legal guidance and support. Given that company fails to protect its own interests in overseas market, sufficient training and guidance on legal rights protection and laws in host country are worthy to be offered by government, whereby companies can be led to use the laws as weapons to protect their legitimate interests, thus in justified reactions to deal with the risk and maintain a positive corporate and national image.

\section{References}

Fu Jinpeng, Fang Min. Evolution of the model of government-enterprise relations [J].Lanzhou Journal, 2004 (1): 27-28.

Luo Danglun, Tang Qingquan. Political relations, social capital and access to policy resources-based on empirical evidence from private listed companies in China [J].World Economy, 2009 (7): 84-96.

Li Rui, Wang Xiaohong. Policy suggestion on vigorously promoting the foreign direct investment of private enterprises-a survey on the foreign direct investment of private enterprises in Hangzhou and Wenzhou, Zhejiang Province [J].Globalization, 2016 (11): 96-103.

Pan Shi, Mo Yan. The essence of enterprise-government relations: the externalization of the duality of Governments' participation [J].Changbai Journal, 2005 (1): 70-73.

Song Biao, Xu Sasha, Ding Qingyang. Game analysis on the evolution of opportunistic behavior of enterprise cooperation and government supervision under the "Belt and Road" Initiative [J].Management Reviews, 2018

Zhu Hongwei. International comparison of government-enterprise relations [J].Economy of the South, 2003 (1): 73-75.

Chou Lihan. The incentive and cooperation of government officials in the game of promotion--reasons for the long-term existence of local protectionism and repetitive construction in China [J].Economic Studies, 2004 (6): 33 40 .

Claessens S, Feijen E, Laeven L. Political connections and preferential access to finance: The role of campaign contributions[J]. Journal of Financial Economics, 2008, 88(3):554-580.

Faccio M . Politically Connected Firms[J]. American Economic Review, 2006, 96(1):369-386.

Fisman R. Estimating the Value of Political Connections[J]. American Economic Review, 2001, 91(4):10951102.

Li H, Meng L, Wang Q, Zhou L, Political Connections, Financing and Firm Performance: Evidence from Chinese Private Firms[J]. Journal of Development Economics, 2008(87): 283 - 299.

Wiwattanakantang Y, Bunkanwanicha P. Big Business Owners in Politics[J]. Review of Financial Studies, 2009, 22(6):2133-2168.

Yu H Y , Main B G M . Political Intervention, Corporate Governance and Firm Performance: An Empirical Investigation in Japan and Taiwan[J]. Social Science Electronic Publishing, 2012, 48(10):1539-1567. 